\title{
Somatic growth from birth to 6 months in low birth weight, in Bukavu, South Kivu, Democratic Republic of the Congo
}

\section{Croissance somatique de la naissance à 6 mois des nouveau-nés de faible poids de naissance à Bukavu, Sud-Kivu, République Démocratique du Congo}

\author{
R. Mbusa-Kambale ${ }^{\mathrm{a}, \mathrm{b}, *}$, M. Mihigo-Akonkwa ${ }^{\mathrm{a}}$, N. Francisca-Isia ${ }^{\mathrm{a}, \mathrm{b}}$, S. Zigabe-Mushamuka ${ }^{\mathrm{a}, \mathrm{b}}$, \\ J. Bwija-Kasengi ${ }^{\mathrm{a}, \mathrm{b}}$, A. Nyakasane-Muhimuzi ${ }^{\mathrm{a}, \mathrm{b}}$, O. Battisti ${ }^{\mathrm{b}, \mathrm{c}}$, B. Mungo-Masumbuko ${ }^{\mathrm{a}, \mathrm{b}}$ \\ ${ }^{a}$ Faculty of Medicine, Catholic University of Bukavu, Bukavu, South-Kivu Province, Democratic Republic of Congo \\ ${ }^{\mathrm{b}}$ Department of Pediatrics, Reference Provincial General Hospital of Bukavu, Bukavu, South-Kivu Province, Democratic Republic of Congo \\ ${ }^{\mathrm{c}}$ Department of Pediatrics, University of Liege, Belgium \\ Received 29 June 2017; accepted 30 November 2017 \\ Available online 30 May 2018
}

\begin{abstract}
Background. - Low birth weight (LBW) is one of the leading causes of perinatal and infant morbidity and mortality, as well as of impaired growth and neurocognitive development. This study aimed to evaluate the evolution of anthropometric parameters and the nutritional status of LBW infants and to analyze factors influencing the growth failure during their first 6 months of life (or adjusted age).

Methods. - This was a prospective cohort study for 6 months, including 100 infants born with LBW and 100 infants born at full-term and with normal weight. The z-scores weight for age, height for age, head circumference for age and weight for height were computed with the software Epinut and WHO Anthro 2005. Descriptive statistics, bivariate analysis and multivariable logistic regression analyses were employed to identify factors associated with growth failure. Growth failure was defined as a decrease in weight z-score (standard deviation score) of over 0.67 during one of the study's periods. The statistical significance threshold was fixed at 0.05 .

Findings. - At 6 months of life (or adjusted age), 15.3\% of LBW were underweight, $51.4 \%$ were stunted, $4.2 \%$ had an emaciation and $25 \%$ had a head circumference for age $<-2 \mathrm{z}$-scores. Risk factor for growth failure was male sex (OR = 1.56 [95\% CI: 1.03-2.23]). The symmetrical intrauterine growth retardation was a protector factor for growth failure $(\mathrm{OR}=0.49$ [95\% CI: $0.25-0.98])$.

Conclusion. - In the short term, LBW infants may have growth disorders. It is necessary to emphasize the importance of growth assessment of LBW children and proper education of their mothers about nutrition of their children for early and timely diagnosis and management of growth retardation and prevention of subsequent problems.
\end{abstract}

(C) 2018 Elsevier Masson SAS. All rights reserved.

Keywords: Low birth weight; Nutritional status; Somatic catch-up; Infant

\section{Résumé}

Introduction. - Le faible poids de naissance (FPN) constitue l'une de principales causes de la morbidité et de la mortalité périnatales, des troubles de croissance somatique et du développement neurocognitif de l'enfant. Cette étude vise à évaluer le statut nutritionnel des nourrissons nés avec un FPN et les facteurs influençant leur échec de croissance durant les 6 premiers mois de vie.

Méthodologie. - Étude de cohorte prospective dynamique incluant 100 nourrissons nés avec un FPN et 100 nourrissons nés à terme et eutrophiques. Les indices poids pour âge, taille pour âge, périmètre crânien pour âge et poids pour taille ont été analysés avec Epinut et WHO

\footnotetext{
* Corresponding author at: Department of Pediatrics, Reference Provincial General Hospital of Bukavu, Bukavu, South-Kivu Province, Democratic Republic of Congo.

E-mail address: richkambale7@gmail.com (R. Mbusa-Kambale).
} 
Anthro 2005. Des statistiques descriptives et des analyses bivariées et multivariées par régression logistique ont été utilisées pour déterminer les facteurs associés aux troubles de croissance. L'échec de croissance a été défini par une diminution de l'écart réduit du poids de plus de 0,67 pendant l'une des périodes d'étude. La valeur de $p<0,05$ a été considérée comme significative.

Résultat. - À six mois de vie, 15,3\% des FPN avaient un déficit pondéral, 51,4\% avaient un retard de croissance, 4,2\% avaient une émaciation et $25 \%$ avaient le périmètre crânien pour âge $<-2$ z-scores. Être de sexe masculin était un facteur de risque d'échec de croissance $(\mathrm{OR}=1,56$ [IC $95 \%: 1,03-2,23])$. Le retard de croissance intra-utérine symétrique représentait un facteur protecteur contre l'échec de croissance $(\mathrm{OR}=0,49$ [IC $95 \%: 0,25-0,98])$.

Conclusion. - À court terme, les nourrissons nés avec un FPN peuvent présenter des troubles de croissance. Les mères des nourrissons nés avec un FPN devraient être sensibilisées sur l'importance du suivi régulier en vue d'un dépistage précoce de ces troubles de croissance. (C) 2018 Elsevier Masson SAS. Tous droits réservés.

Mots clés : Faible poids de naissance ; Statut nutritionnel ; Rattrapage somatique ; Nourrisson

\section{Introduction}

Low birth weight (LBW), defined as birth weight less than $2500 \mathrm{~g}$ [1], is a real public health issue. It is the result of prematurity or intra-uterine growth retardation (IUGR) or being small for gestational age (SGA) [2]. The causes of prematurity and those of IUGR are well known [3-5]. LBW is a concern of both parents and health professionals. It is one of the leading causes of perinatal and infant morbidity and mortality, longterm metabolic disorders, and impaired growth and neurocognitive development [5-7]. Worldwide, more than 20 million infants are born with LBW each year, representing a global prevalence of $15.5 \%$. Approximately $95 \%$ of these LBW occur in low- and middle-income countries (LMICs) [8]. In the Democratic Republic of Congo (DRC), the prevalence of LBW has varied over the years, ranging from $11 \%$ in 2001 [9] to $7.1 \%$ in 2014 [10]. Growth monitoring is of particular importance in a developing country such as DRC where there are high rates of malnutrition and infectious diseases [11], a crude mortality rate above the average for sub-Saharan countries [12] and the highest under-5 mortality rate in Africa [13,14]. Growth monitoring in LBW infants is, however, complicated by several factors. Foremostly, the growth of LBW infants is characterized by early suboptimal growth followed by a period of catch-up growth $[15,16]$. Secondly, LBW infants are a heterogeneous group of variable birth weight, sex, gestational ages, associated morbidities and appropriateness for gestational age, all factors which affect growth [15-18]. Thirdly, controversy surrounds the ideal growth of LBW infants: rapid catch-up growth is advantageous with respect to improved neurodevelopmental outcomes, fewer psychosocial problems in later childhood and lower risk of persistent short stature but may be associated with an increased risk of childhood obesity and other metabolic complications [15,19]. Almost nothing is known about the growth of LBW infants in the DRC. The aim of this study was to evaluate the growth parameters (weight, length and head circumference) from birth to 6 months of age (or gestationadjusted age) of LBW infants admitted to the neonatology unit and later followed in the maternal and child health unit (MCHU) of Reference Provincial General Hospital of Bukavu (RPGHB). Secondly, this study aimed to analyze factors influencing growth failure during the first 6 months of life.

\section{Population and methods}

\subsection{Study area}

This dynamic prospective cohort study was carried out in outpatient infants in the MCHU of RPGHB. This hospital has 385 beds, handles 6400 admissions and 4900 outpatients per year. It is one of the main healthcare facilities in Bukavu, a city of more than 700,000 inhabitants in South-Kivu Province in eastern DRC. It organizes tertiary care services. Within the RPGHB, MCHU activities are carried out by the pediatrics and obstetrics departments. This study was carried out in the MCHU of the pediatrics department, which provides pre-school counselling and vaccination of children and maternal health education.

\subsection{Sample size}

An external follow-up program in the MCHU for all infants born in RPGHB has been established by the pediatrics department since January 2016 in order to ensure early screening of impaired growth in children. Follow-up is organized after informed consent from the mother. Thus, from January to December 2016, 183 LBW infants and 413 infants born at full-term and with normal weight (FTNW) were followed in the MCHU of RPGHB. These newborns were selected as they arrived in RPGHB and each was followed for 6 months in the MCHU. The size of our sample was calculated by the Lorentz formula:

$n=\frac{t^{2} \cdot p \cdot(1-p)}{m^{2}}=\frac{(1.96)^{2} \cdot 0.07 \cdot 0.93}{(0.05)^{2}}$

$\approx 100$ individuals ( $n$ : sample size; $t: 95 \%$ confidence level [typical value 1.96]; $P$ : probability of LBW [7\% according to Demographic and Health Surveys DRC 2014]; m: margin of error [5\%]).

These 100 individuals were randomly selected from this population of $183 \mathrm{LBW}$ infants, based on a simple random sampling. We also randomly selected, from a simple random sampling, 100 control individuals from this population of 413 FTNW infants (Fig. 1). 


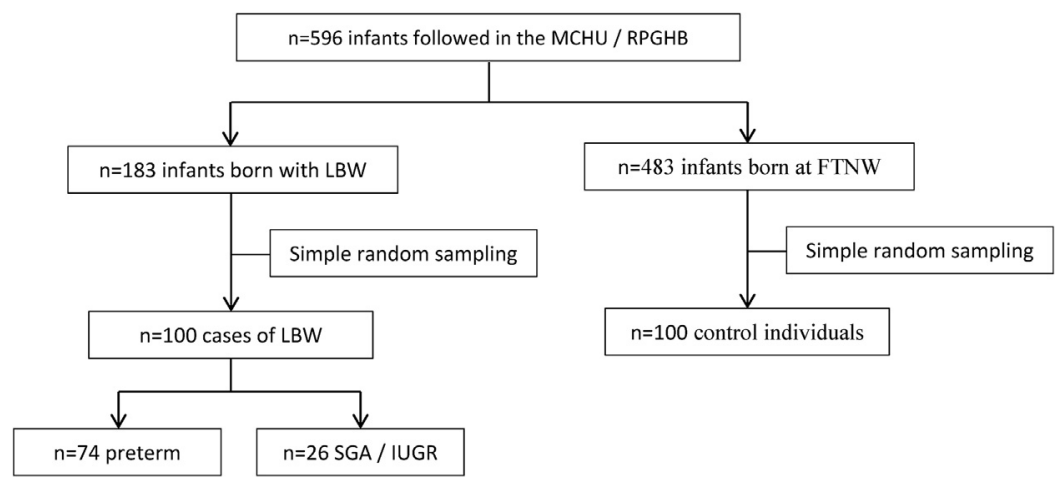

Fig. 1. Flow chart for infants followed in MCHU/RPGHB. MCHU: maternal and child health unit; RPGHB: Reference Provincial General Hospital of Bukavu; LBW: low birth weight; SGA: small for gestational age; IUGR: intra-uterine growth retardation; FTNW: full-term and normal weight.

\subsection{Inclusion and exclusion criteria}

The study included infants with the following characteristics:

- birth weight less than $2500 \mathrm{~g}$ and;

- informed consent of the mother obtained. Infants from twin pregnancies and those whose mothers refused an external follow-up to the RPGHB were excluded.

\subsection{Data collection}

\subsubsection{Description of population}

In the neonatology unit, a questionnaire was administered to collect the following information on mothers:

- maternal age (in years);

- parity (primipara/multipara);

- education status (unschooled/primary school/secondary school/university);

- marital status (married/unmarried);

- socioeconomic status (low/medium/good);

- sibling size $(\leq 5 />5)$;

- interpregnancy interval ( $<24$ months/ $\geq 24$ months) and;

- parent occupation.

Information on newborns were collected from mothers and in medical records of the neonatology unit. Data collected were:

- gender (male/female);

- gestational age (preterm infant/full-term infant);

- trophicity (SGA/IUGR/AGA);

- anthropometric birth parameters: weight (in gram), length (in $\mathrm{cm}$ ) and head circumference $(\mathrm{cm})$.

The mother's school level was subdivided into two classes: low (for mothers unschooled or primary school), good (for those having secondary school or university). The socioeconomic status was determined on the basis of a household wealth score as proposed by Bangirana et al. [20] and Filmer et al. [21] on the basis of the household's material assets and on the basis of several characteristics of the house such as materials used for walls and for the roof. The household wealth score was obtained by adding up the points assigned to the above items. Preterm infant was defined as an infant born before 37 weeks of gestational age and a full-term infant as an infant born between 37 and 42 weeks of gestational age [22]. SGA was defined, firstly, as a birth weight below the 3rd percentile of the AUDIPOG's reference of birth weight-for-gestational-age [23], which is gender specific as recommended by the WHO; secondly, SGA was defined by harmonious anthropometry; IUGR was defined as a birth weight below the 3rd percentile of the AUDIPOG's reference of birth weight-for-gestational-age and with non-harmonious anthropometry; AGA was defined as an infant whose birth weight is between the 3rd percentile and the 97th percentile of the AUDIPOG's reference of birth weight-for-gestational-age. Rohrer's ponderal index in newborns $\left(\mathrm{PI}=\frac{\text { Weight }(\text { in } \mathrm{g})}{\left(\text { height }(\text { in } \mathrm{cm})^{3}\right)} \times 100\right)$ has been used to assess symmetrical or asymmetrical IUGR.

\subsubsection{Anthropometric measurements and feeding practices}

After hospital discharge, the newborns were reviewed in consultation two weeks later and then once a month for up to 6 months in the MCHU. Weight was measured using an electronic baby scale $\left(\mathrm{SECA}^{\mathbb{R}}\right.$ type 435$)$ with a precision of $10 \mathrm{~g}$. Length was measured to the nearest millimeter using a gauge (ADE-Mechanical Baby Length Measuring gauge). The head circumference (HC) was measured as the maximum occipito-frontal circumference using a non-stretchable tape measure. Weight, length and $\mathrm{HC}$ were measured according to the methods recommended by WHO 1995 [24]. Measurements were taken twice, by two different operators and the mean of each was noted. For infants born preterm, the anthropometric parameters and the monthly nutritional indices were considered according to the gestation-adjusted age of infants. The z-scores weight for age (WAZ), height for age (HAZ), weight for height (WHZ) and HC for age (HCAZ) were used to define the nutritional status of infants. Acute malnutrition (emaciation), chronic malnutrition (stunting) and underweight were defined according to the WHO 2006 criteria: for emaciation, a WHZ $<-2$, and/or bilateral nutritional edema. Stunting was defined as a $\mathrm{HAZ}<-2$. Underweight was defined as the 
$\mathrm{WAZ}<-2[25,26]$. As suggested by Ong et al. [27], growth failure was defined as a decrease in weight $\mathrm{z}$-score of over 0.67 (i.e. over $0.67 \mathrm{SD}$ ) during any of study periods. A questionnaire was also administered monthly to collect information about breastfeeding and to assess the quality of feeding practices through a qualitative 24-hour dietary recall, according to the WHO recommendations $[28,29]$.

\subsubsection{Ethical considerations}

The study was explained to women previously during their stay in neonatology unit and in the maternity. Ethical approval was granted by the Ethical Committee of the Catholic University of Bukavu, DRC. In order to guarantee the confidentiality of the information given by the participants in the study, data were reviewed and analyzed anonymously.

\subsection{Statistical analysis}

The data were analyzed using SPSS software version 20. The nutritional indices WAZ, HAZ, HCAZ and WHZ were computed with the software Epinut, version 3.3.2 (Center for Disease Control and Prevention, Atlanta) and WHO Anthro 2005. Proportions were compared by using either the $\chi^{2}$ or the Fisher exact test. The nonparametric Kruskall-Wallis test was used for the comparison of quantitative variables. Logistic regression was used to quantify the association between growth failure and sociodemographic and nutritional factors in multivariate analysis. Incidence rate ratios (IRR) and their 95\% confidence intervals (95\% CI) were computed by using the group in which the incidence was the lowest as reference. The statistical significance threshold was fixed at 0.05.

\section{Results}

The characteristics of all mothers and infants are summarized in Table 1. During the overall follow-up of the 200 mother-child pairs, 5144 WAZ, HAZ, HCAZ and WHZ values were computed. The rate of missing WAZ, HAZ, HCAZ and WHZ data was $0.29 \%$ to the first month to $20 \%$ at the 6th month.

Growth measurements at the various time points of the study are summarized in Table 2. During the entire follow-up period, mean $\mathrm{z}$-scores for WAZ and HAZ remained negative at all time points along the line of usual progression according to age, indicating that children in this population were restricted in growth and stunted compared with the reference population (WHO 2006). Mean z-scores for WHZ remained negative from birth to 3 months of life (or adjusted age), indicating that children were thinner than the reference population (WHO 2006) during that period. At 6 months of life (or gestationadjusted age), the prevalences of underweight, stunted growth and emaciation were, respectively, $22.3 \%$ (15.3\% for LBW and $7 \%$ for no LBW), $64.3 \%$ (51.4\% for LBW $13 \%$ for no LBW) and $7.2 \%$ (4.2\% for LBW and $3 \%$ for no LBW). Eighteen (25\%) LBW infants had a low HC for age.

The progression of growth failure at the various time points of the study is summarized in Fig. 2. Seventeen (17\%, or 17 of
Table 1

Baseline characteristics of the 200 mother-child pairs followed in the MCHU/ RPGHB from January to December 2016.

\begin{tabular}{|c|c|c|}
\hline & $\begin{array}{l}\text { LBW } \\
n(\%)\end{array}$ & $\begin{array}{l}\text { No LBW } \\
n(\%)\end{array}$ \\
\hline $\begin{array}{l}\text { Maternal age (in years) [Median } \\
\quad(\min -\max )]\end{array}$ & $25(16-40)$ & $27(16-45)$ \\
\hline$<18$ & $2(2)$ & $1(1)$ \\
\hline $18-35$ & $94(94)$ & $88(88)$ \\
\hline$\geq 35$ & $4(4)$ & $11(11)$ \\
\hline \multicolumn{3}{|l|}{ Marital status } \\
\hline Married & $96(96)$ & $95(95)$ \\
\hline Unmarried & $4(4)$ & $5(5)$ \\
\hline Parity [Median (min-max)] & $2(1-7)$ & $3(1-8)$ \\
\hline Primipara & $42(42)$ & $34(34)$ \\
\hline Multipara & $58(58)$ & $66(66)$ \\
\hline \multicolumn{3}{|l|}{ Mother's schooling status } \\
\hline Unschooled & $5(5)$ & $3(3)$ \\
\hline Primary school & $10(10)$ & $14(14)$ \\
\hline Secondary school & $42(42)$ & $33(33)$ \\
\hline University school & $43(43)$ & $50(50)$ \\
\hline \multicolumn{3}{|l|}{ Socioeconomic status } \\
\hline Low & $41(41)$ & $29(29)$ \\
\hline Medium & $33(33)$ & $24(24)$ \\
\hline Good & $26(26)$ & $47(47)$ \\
\hline $\begin{array}{l}\text { Interpregnancy interval [Median } \\
\quad(\min -\max )]\end{array}$ & $34(11-108)$ & $18(14-106)$ \\
\hline$<24$ months & $20 / 58(34.5)$ & $26 / 65(40)$ \\
\hline$\geq 24$ months & $38 / 58(65.5)$ & $39 / 65(60)$ \\
\hline Sibling size [Median (min-max)] & $2(1-7)$ & $2(1-11)$ \\
\hline$<5$ & $93(93)$ & $80(80)$ \\
\hline$\geq 5$ & $7(7)$ & $20(20)$ \\
\hline \multicolumn{3}{|l|}{$\operatorname{Sex}$} \\
\hline Male & $52(52)$ & $58(58)$ \\
\hline Female & $48(48)$ & $42(42)$ \\
\hline \multicolumn{3}{|l|}{ Types of newborns } \\
\hline Preterm infants & $74(74)$ & 0 \\
\hline Full term infants & $26(26)$ & $100(100)$ \\
\hline No IUGR & $67(67)$ & $100(100)$ \\
\hline IUGR & $33(33)$ & 0 \\
\hline Asymmetrical IUGR & $7(21.2)$ & 0 \\
\hline Symmetrical IUGR & $26(78.8)$ & 0 \\
\hline \multicolumn{3}{|l|}{ Birth anthropometric parameters } \\
\hline $\begin{array}{l}\text { Birth weight (in grams) } \\
{[\text { Mean } \pm \text { SD] }}\end{array}$ & $1997.2 \pm 411$ & $3290.4 \pm 327$ \\
\hline Birth length (in $\mathrm{cm}$ ) $[$ Mean $\pm \mathrm{SD}]$ & $43.3 \pm 3.7$ & $50.2 \pm 1.6$ \\
\hline $\begin{array}{l}\text { Birth head circumference (in } \mathrm{cm} \text { ) } \\
{[\text { Mean } \pm \mathrm{SD}]}\end{array}$ & $30.9 \pm 1.9$ & $35.0 \pm 0.9$ \\
\hline \multicolumn{3}{|l|}{$\begin{array}{l}\text { Mean daily weight gain and Median } \\
\text { length of stay }\end{array}$} \\
\hline $\begin{array}{l}\text { Mean daily weight gain (in } \mathrm{g} / \mathrm{kg} / \\
\text { day) [Median (min-max)] }\end{array}$ & $17(5-31)$ & $22.7(10-33.3)$ \\
\hline $\begin{array}{l}\text { Median length of stay (in days) } \\
\text { [Median (min-max)] }\end{array}$ & $11(2-69)$ & $3(1-5)$ \\
\hline
\end{tabular}

MCHU: maternal and child health unit; RPGHB: Reference Provincial General Hospital of Bukavu; LBW: Low birth weight; IUGR: Intra-uterine growth retardation.

100) LBW infants exhibited growth failure during the first month, 4 (4.9\%, or 4 of 81 ) during the 3rd month and 1 (1.4\%, or 1 of 72) during the 6th month. For no LBW infants, the prevalence of growth failure was $24 \%$ the first month and $3 \%$ the 6th month.

Nutritional characteristics of the 200 mother-child pairs are summarized in Table 3 . The prevalence of exclusive 
Table 2

Growth measurements and outcomes.

\begin{tabular}{|c|c|c|c|c|c|c|c|c|c|c|c|c|c|c|}
\hline & \multicolumn{14}{|c|}{ Study time points } \\
\hline & \multicolumn{2}{|l|}{ Birth } & \multicolumn{2}{|l|}{$\begin{array}{l}1 \text { month } \\
\text { of life (or } \\
\text { corrected age) }\end{array}$} & \multicolumn{2}{|l|}{$\begin{array}{l}2 \text { months } \\
\text { of life (or } \\
\text { corrected age) }\end{array}$} & \multicolumn{2}{|l|}{$\begin{array}{l}3 \text { months } \\
\text { of life (or } \\
\text { corrected age) }\end{array}$} & \multicolumn{2}{|l|}{$\begin{array}{l}4 \text { months } \\
\text { of life (or } \\
\text { corrected age) }\end{array}$} & \multicolumn{2}{|l|}{$\begin{array}{l}5 \text { months } \\
\text { of life (or } \\
\text { corrected age) }\end{array}$} & \multicolumn{2}{|l|}{$\begin{array}{l}6 \text { months } \\
\text { of life (or } \\
\text { corrected age) }\end{array}$} \\
\hline & $\begin{array}{l}\text { LBW } \\
(n=100)\end{array}$ & $\begin{array}{l}\text { No LBW } \\
(n=100)\end{array}$ & $\begin{array}{l}\text { LBW } \\
(n=96)\end{array}$ & $\begin{array}{l}\text { No LBW } \\
(n=100)\end{array}$ & $\begin{array}{l}\text { LBW } \\
(n=84)\end{array}$ & $\begin{array}{l}\text { No LBW } \\
(n=100)\end{array}$ & $\begin{array}{l}\text { LBW } \\
(n=81)\end{array}$ & $\begin{array}{l}\text { No LBW } \\
(n=100)\end{array}$ & $\begin{array}{l}\text { LBW } \\
(n=80)\end{array}$ & $\begin{array}{l}\text { No LBW } \\
(n=100)\end{array}$ & $\begin{array}{l}\text { LBW } \\
(n=73)\end{array}$ & $\begin{array}{l}\text { No LBW } \\
(n=100)\end{array}$ & $\begin{array}{l}\text { LBW } \\
(n=72)\end{array}$ & $\begin{array}{l}\text { No LBW } \\
(n=72)\end{array}$ \\
\hline \multicolumn{15}{|l|}{ Weight } \\
\hline Mean (kg) (SD) & $1.9(0.4)$ & $3.3(0)$ & $2.9(0.7)$ & $4.4(0.5)$ & $3.9(0.8)$ & $5.3(0.7)$ & $4.8(0.8)$ & $6.0(0.8)$ & $5.5(0.7)$ & $6.6(1)$ & $6.1(0.7)$ & $7.1(0.9)$ & $6.7(0.7)$ & $7.6(1)$ \\
\hline Mean z score (SD) & $-3.1(1.12)$ & $-0.04(0.70)$ & $-2.80(1.32)$ & $-0.02(0.83)$ & $-2.42(1.47)$ & $-0.26(1.05)$ & $-2.09(1.33)$ & $-0.22(1.09)$ & $-1.70(1.17)$ & $-0.27(1.05)$ & $-1.40(1.14)$ & $-0.24(1.08)$ & $-1.07(1.97)$ & $-0.29(1.12)$ \\
\hline $\mathrm{WAZ}<-2, n(\%)$ & $79(79)$ & $1(1)$ & $67(69.8)$ & 0 & $52(61.9)$ & $5(5)$ & $44(54.3)$ & $7(7)$ & $32(40)$ & $6(6)$ & $19(26)$ & $6(6)$ & $11(15.3)$ & $7(7)$ \\
\hline \multicolumn{15}{|l|}{ Height } \\
\hline Mean $(\mathrm{cm})(\mathrm{SD})$ & $43.3(3.6)$ & $50.2(1.6)$ & $49.1(3.9)$ & $53.9(1.9)$ & $52.4(3.7)$ & $56.6(2.1)$ & $55.3(3.4)$ & $59.1(2.3)$ & $57.8(3.9)$ & $61.5(2.3)$ & $59.8(4.0)$ & $63.6(2.4)$ & $61.9(4.1)$ & $65.6(2.6)$ \\
\hline Mean z score (SD) & $-2.99(1.51)$ & $-0.36(0.84)$ & $-2.94(1.54)$ & $-0.15(0.94)$ & $-2.74(1.65)$ & $-0.65(1.05)$ & $-2.50(1.48)$ & $-0.76(1.10)$ & $-2.33(1.45)$ & $-0.81(1.07)$ & $-2.14(1.37)$ & $-0.73(1.12)$ & $-2.04(1.43)$ & $-0.62(1.18)$ \\
\hline HAZ $<-2, n(\%)$ & 74 (74) & $2(2)$ & $55(58.5)$ & 0 & $53(63.1)$ & $13(13)$ & $50(61.7)$ & $16(16)$ & $44(55)$ & $17(17)$ & $37(50.7)$ & $13(13)$ & $37(51.4)$ & $13(13)$ \\
\hline \multicolumn{15}{|l|}{ Head circumference } \\
\hline Mean (cm) (SD) & 30.9 (1.9) & $35.0(0.9)$ & 34.4 (1.9) & $37.3(0.9)$ & 36.4 (1.9) & $38.7(1.2)$ & $38.1(1.8)$ & $40.0(1.4)$ & $39.4(1.8)$ & $41.2(1.5)$ & $40.5(1.7)$ & $42.5(1.5)$ & $41.8(1.8)$ & $43.5(1.6)$ \\
\hline Mean z score (SD) & $-2.7(1.54)$ & $0.7(0.8)$ & $-2.0(1.52)$ & $0.2(0.87)$ & $-2.2(1.57)$ & $-0.3(1.02)$ & $-1.8(1.56)$ & $-0.3(1.19)$ & $-1.5(1.42)$ & $-0.1(1.22)$ & $-1.3(1.4)$ & $0.08(1.24)$ & $-0.8(1.34)$ & $0.3(1.23)$ \\
\hline $\mathrm{HCAZ}<-2, n(\%)$ & $63(63)$ & 0 & $49(51.0)$ & 0 & $37(44.0)$ & 0 & $34(42.5)$ & $7(7)$ & $31(38.8)$ & $8(8)$ & $27(37.5)$ & $7(7)$ & $18(25)$ & $4(4)$ \\
\hline \multicolumn{15}{|l|}{ Weight for height } \\
\hline Mean z score (SD) & $-1.84(1.26)$ & $-0.41(1.0)$ & $-1.15(1.54)$ & $0.35(1.31)$ & $-0.11(1.61)$ & $-0.67(1.40)$ & $0.38(1.36)$ & $0.58(1.45)$ & $0.53(1.14)$ & $0.38(1.07)$ & $0.60(1.21)$ & $0.23(1.40)$ & $0.65(1.20)$ & $0.04(1.35)$ \\
\hline $\mathrm{WHZ}<-2, n(\%)$ & $80(80)$ & 7 (7) & $40(42.6)$ & $9(9)$ & $15(17.9)$ & $8(8)$ & $7(8.6)$ & $10(10)$ & $6(7.5)$ & $6(6)$ & $6(8.2)$ & $5(5)$ & $3(4.2)$ & $3(3)$ \\
\hline
\end{tabular}

LBW: low birth weight; WAZ: weight for age z-score; HAZ: height for age z-score; HCAZ: head circumference for age z-score; WHZ: weight for height z-score. 


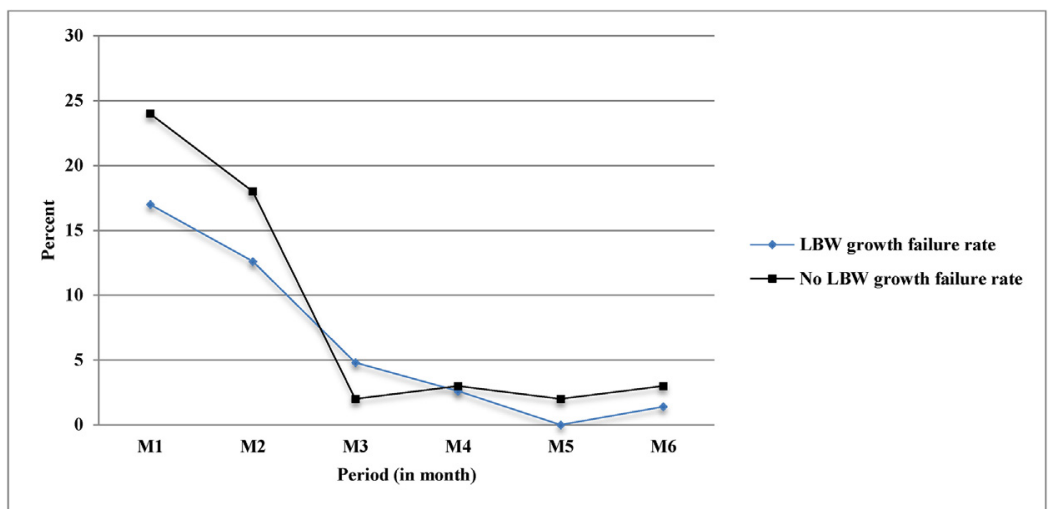

Fig. 2. Evolution of growth failure at the various time points of the study. LBW: low birth weight; No LBW: no low birth weight; M: month.

Table 3

Nutritional characteristics of the 200 mother-child pairs followed in the MCHU/RPGHB from January to December 2016.

\begin{tabular}{lll}
\hline & $\begin{array}{l}\text { LBW } \\
n(\%)\end{array}$ & $\begin{array}{l}\text { No LBW } \\
n(\%)\end{array}$ \\
\hline $\begin{array}{ll}\text { Exclusive breastfeeding (Mean } \pm S D) \\
\text { Until } 6 \text { months }\end{array}$ & $4.5 \pm 1.1$ & $5.2 \pm 1.6$ \\
Under 6 months & $72(72)$ & $63(63)$ \\
Complementary food & $28(28)$ & $37(37)$ \\
Preterm formula & $n=28$ & $n=37$ \\
First infant formula & $17(60.7)$ & 0 \\
Protein-enriched porridge & $11(39.3)$ & $18(48.7)$ \\
Non protein-enriched porridge & 0 & $16(43.2)$ \\
Solid or semi-solid foods & 0 & $1(2.7)$ \\
Causes of exclusive breastfeeding under 6 months & 0 & $2(5.4)$ \\
Low breast milk production & $n=31$ & $n=37$ \\
Going back to work & $22(70.9)$ & $11(29.8)$ \\
The baby was not satisfied by breast milk & $5(16.1)$ & $13(35.1)$ \\
Mastitis & $1(3.3)$ & $4(10.8)$ \\
I did not know the moment of dietary diversity & 0 & $3(8.1)$ \\
Continued breastfeeding & $100(100)$ & $100(100)$ \\
\hline
\end{tabular}

MCHU: Maternal and child health unit; RPGHB: Reference Provincial General Hospital of Bukavu.

breastfeeding was $72 \%$ for LBW infants and $63 \%$ for no LBW infants. Seventeen $(60.7 \%$, or 17 of 28$)$ infants were fed with preterm formula and breastfeeding. The mean age of introducing complementary food was 4.5 months for LBW infants and 5 months for no LBW infants. All mothers continued breastfeeding after 6 months.

Table 4 summarizes the risk factors associated with growth failure. In multivariate analysis, only male sex $(\mathrm{OR}=1.56$ [95\% CI: 1.03-2.23]) was associated with the risk of growth failure. The symmetrical IUGR was a protector factor of growth failure $(\mathrm{OR}=0.49$ [95\% CI: 0.25-0.98]).

\section{Discussion}

The main objective of this study was to evaluate the evolution of anthropometric parameters and the nutritional status of LBW infants and to analyze factors influencing growth failure during their first 6 months of life. At 6 months of life (or adjusted age), $15.3 \%$ of LBW infants were underweight, $51.4 \%$ were stunted and $4.2 \%$ exhibited emaciation. Male gender was significantly associated with growth failure. We did not find any association between LBW infant diet and growth failure.

In a retrospective study of 24,371 preterm infants in the USA, Clark et al. [30] reported stunting (34\%), underweight (28\%), and a low HC for age (16\%). Another study carried out in Israel by Marks et al. [31] and involving 5977 preterm infants reported that $10.6 \%$ were underweight. High rates of post-natal stunting and underweight have been reported mostly in Africa and Asia. In Senegal, Faye et al. [32] reported extra-uterine growth retardation $(86 \%)$, underweight $(61 \%)$, and underweight at 40 weeks post-conception (41\%), at 3 months and at 6 months of gestation-adjusted age. Other higher rates of underweight were reported in Morocco (77.5\%) [33], Tunisia (55\%) [34], China (56.8\%) [35] and Japan (49\%) [36].

In the medium term, nutritional disturbances are also of interest to infants with a history of IUGR. In Nigeria, Olusanya et al. [37], in a cross-sectional survey to assess the impact of IUGR on growth at one week of life, showed an association between IUGR and nutritional disturbances, results confirmed later in this same cohort at the age of 3 months [38]. Comparable results on various anthropometric indices have been described in Kenya [39], Ethiopia [40] and Malawi [41].

In our report, chronic malnutrition seems to be much more important than acute malnutrition and this could be considered as a criterion for the validity of our data. However, these results are worrisome because they seem to indicate that within two years, more than half of the population shows growth disturbances. This is consistent with the demographic and health survey (DHS) of DRC-2014 showing, in South Kivu province, a chronic malnutrition rate of $53 \%$ among children under 5 (the highest in the DRC). Size growth is a more robust measure because it evolves cumulatively until the age of 2 years and then stabilizes in plateau. Weight is a labile measure that peaks between 12 and 18 months. Acute malnutrition is therefore a condition that can vary rapidly over time and is highly dependent on the child's health or a limited period of nutritional deprivation.

The rate of exclusive breastfeeding in our study is higher than the national rate. According to the DHS-DRC, in 2014, 
Table 4

Comparison of growth of infants with and without growth failure.

\begin{tabular}{|c|c|c|c|c|}
\hline & Growth failure & No growth failure & Adjusted OR (95\% CI) & $P$-value \\
\hline \multicolumn{5}{|l|}{ Socioeconomic status } \\
\hline Low & $11(27.5)$ & $29(72.5)$ & $0.85(0.42-1.71)$ & 0.65 \\
\hline Medium & $11(32.4)$ & $23(67.6)$ & 1 & \\
\hline Good & $10(38.5)$ & $16(61.5)$ & $1.18(0.59-2.36)$ & 0.62 \\
\hline \multicolumn{5}{|l|}{ Interpregnancy interval } \\
\hline$<24$ months & $23(37.1)$ & 39 (62.9) & $1.56(0.81-3.01)$ & 0.16 \\
\hline$\geq 24$ months & $9(23.7)$ & $29(76.3)$ & 1 & \\
\hline \multicolumn{5}{|l|}{ Infant sex } \\
\hline Male & $18(37.5)$ & $30(62.5)$ & $1.56(1.03-2.33)$ & 0.027 \\
\hline Female & $14(26.9)$ & $38(73.1)$ & 1 & \\
\hline \multicolumn{5}{|l|}{ Type of newborns } \\
\hline Preterm infants & $20(27.0)$ & $54(73.0)$ & $0.58(0.33-1.02)$ & 0.07 \\
\hline Full term infants & $12(46.2)$ & $14(53.8)$ & 1 & \\
\hline IUGR & $13(39.4)$ & $20(60.6)$ & $1.39(0.78-2.45)$ & 0.27 \\
\hline No IUGR & $19(28.4)$ & 48 (71.6) & 1 & \\
\hline Symmetrical IUGR & $1(14.3)$ & $6(85.7)$ & $0.31(0.04-0.9)$ & 0.018 \\
\hline Asymmetrical IUGR & $12(46.2)$ & $14(53.8)$ & & \\
\hline \multicolumn{5}{|l|}{ Complementary food } \\
\hline Exclusive breastfeeding & $23(31.8)$ & $49(68.1)$ & $0.90(0.43-1.87)$ & 0.79 \\
\hline First infant formula + breastfeeding & $3(27.3)$ & $8(72.7)$ & $0.77(0.24-2.46)$ & 0.41 \\
\hline Preterm formula + breastfeeding & $6(35.3)$ & $11(64.7)$ & 1 & \\
\hline
\end{tabular}

IUGR: intra-uterine growth retardation.

$48 \%$ of children under 6 months of age were exclusively breastfed. The practice of exclusive breastfeeding during the first six months is in a growing trend, with an estimated $24 \%$ in $2001,36 \%$ in $2007,37 \%$ in 2010 and $48 \%$ in 2014 [10].

Many factors influence the postnatal growth of LBW infants. Since 1948, nutritional practices have been identified as the main cause of the postnatal growth restriction observed in preterm infants [42]. This restriction of postnatal growth is explained by the high energy requirements of these growing children and neonatal pathologies [43]. In 2001, Embleton et al. [44] demonstrated the importance of the cumulative nutritional deficit that occurs during the first weeks of life, stressing that it does not subside during the hospital stay of preterm infants. Based on recommendations of $120 \mathrm{kcal} / \mathrm{kg} / \mathrm{d}$ with $3 \mathrm{~g} / \mathrm{kg} / \mathrm{d}$ of protein, the authors described, after one week of life in preterm infants of $\leq 30$ weeks, a cumulative nutritional deficit of $406 \pm 92 \mathrm{kcal} / \mathrm{kg}$ and $14 \pm 3 \mathrm{~g} / \mathrm{kg}$ protein, corresponding to $48 \%$ and $67 \%$ of the theoretical cumulative intakes of the first week, respectively. Other nutritional studies in very preterm infants confirmed that they accumulate a major protein-energy deficiency during the first week of life; this deficit persists and it is associated with severe postnatal growth restriction [4547]. This cumulative deficit of protein-energy intake during the first few weeks of life seems to be responsible for half of the post-natal growth restriction observed in these very preterm infants [43] and, in particular, protein deficiency in the first days of life $[47,48]$.

Being male is another risk factor of impaired growth in LBW infants reported in some studies. Indeed, Kabore et al. [49] in Burkina Faso and Kalanda et al. [50] in Malawi described a high prevalence of stunting and underweight in male infants. Similar observations were also made by Wamani et al. [51] in Uganda, Van de Poel et al. [52] in Ghana, Ukwuani et al. [53] in
Nigeria and Medhin et al. [40] in Ethiopia. This observation was confirmed by a meta-analysis in 16 countries in subSaharan Africa [54]. Several hypotheses have been put forward to explain this growth differential between girls and boys: Medhin et al. [40] in Ethiopia and Padonou et al. [55] in Benin reported the high prevalence of anemia among boys in their study populations to explain their poor growth. Well [56], on the other hand, referred to the hypothesis that genetic factors could explain the relative vulnerability of boys to girls. Recently, Warrington et al. [57] demonstrated an interaction between genetic polymorphisms and sex, indicating that the age at which genetic growth disorders occur, differs between boys and girls.

Our report demonstrated that the symmetrical IUGR was a protector factor of growth failure. Bocca-Tjeertes et al., in a study examining how symmetric growth restriction and asymmetric growth restriction influence growth and development in preterms from birth to 4 years, reported that up to age 4 years, symmetric growth restriction and asymmetric growth restriction preterm-born children failed to catch up on weight and height sufficiently, and that these preterm children could not keep up with the growth velocity of their non-growth restriction counter-parts. But, on the other hand, the $\mathrm{HC}$ growth of symmetric growth restriction exceeded that of asymmetric growth restriction and non-growth restriction, but still remained lower at age 1 year [58].

\section{Conclusion}

This study focused on the analysis of the somatic growth of LBW infants, followed between January and December 2016 in the MCHU of RPGHB in South-Kivu Province in eastern DRC. The aim was to evaluate nutritional status of infants born LBW 
and to analyze factors influencing their growth during their first 6 months of life. Different risk factors for impaired growth of LBW infants have been identified. Information, education and communication for mothers about the importance of this follow-up can be helpful in rapidly detecting and remedying these growth problems. In addition, other long-term research involving the aspects of neurocognitive development should be carried out to ensure that these infants receive global and optimal care.

\section{Disclosure of interest}

The authors declare that they have no competing interest. Acknowledgments

We thank the entire staff of the Pediatrics and Obstetrics Departments at RPGHB for their technical assistance. We also gratefully acknowledge the study's participants.

\section{References}

[1] World Health Organization (WHO). Aspects of low birth weight. Report of the expert committee of maternal child health. WHO technical report 1961;217:3-16.

[2] Sherry B, Mei Z, Grummer -Strawn L, Dietz W. Evaluation of and recommendations for growth references for very low birth weight $(<$ or $=1500$ grams $)$ infants in the United States. Pediatrics 2003;111:750-8 [4 Pt 1].

[3] Goldenberg RL, Culhane JF, Iams JD, Romero R. Epidemiology and causes of preterm birth. Lancet 2008;371(9606):75-84.

[4] Mandruzzato G, Antsaklis A, Botet F, Chervenak FA, Figueras F, Grunebaum A, et al. Intrauterine restriction (IUGR). J Perinat Med 2008;36(4):277-81.

[5] Valero De Bernabé J, Soriano T, Albaladejo R, Juarranz M, Calle ME, Martínez D, et al. Risk factor of low birth weight: a review. Eur J Obstet Gynecol Reprod Biol 2004;116:3-15.

[6] Ngoc NT, Merialdi M, Abdel-Aleem H, Carroli G, Purwar M, Zavaleta N, et al. Causes of stillbirth and early neonatal birth: data of 7993 pregnancies in six developing countries. Bull World Health Organ 2006;84:699-705.

[7] Bari MI, Ullah MA, Khatum M. Morbidity and mortality of low birth weight baby. TAJ 2008;21(1):35-9.

[8] W.H.O, UNICEF. Low birthweight: country regional and global estimates.. Geneva: United Nations Children's Fund and World Health Organization; 2004.

[9] Ministère du Plan Institut National de la Statistique. Enquête par grappes à indicateurs multiples MICS République Démocratique du Congo; 2001.

[10] Ministère du Plan Institut National de la Statistique. Enquête Démocratique et de santé II, rapport final, République Démocratique du Congo, 2013-2014; 2014.

[11] Moszynski P. 5.4 million people have died in Democratic Republic of Congo since 1998 because of conflict, report says. BMJ 2008;336(7638):235 [https://doi.org/10.101136/bmj.39475.524282.DB].

[12] Coghlan B, Brennan RJ, Ngoy. et al. Mortality in the Democratic Republic of Congo: a nationwide survey. Lancet 2006;367(9504):44-51 [https:// doi.org/10.1016/S0140-6736(06)67923-3].

[13] Kandala NB, Emina JB, Nzita PD, et al. Diarrhoea, acute respiratory infection, and fever among children in the Democratic Republic of Congo. Soc Sci Med 2009;68(8):1728-36 [https://doi.org/10.1016/j.socscimed.2009.02.004].

[14] Black RE, Cousens S, Johnson HL, et al. Global, regional, and national causes of child mortality in 2008: a systematic analysis. Lancet 2010;375(9730):1969-11987 [https://doi.org/10.1016/S0140-6736(10) 60549-1].
[15] Niklasson A, Engstrom E, Hard AL, Wikland KA, Hellstrom A. Growth in very preterm children: a longitudinal study. Pediatr Res 2003;54(6):899-905. http://dx.doi.org/10.1203/01.PDR [0000091287. 38691.EF].

[16] Knops NB, Sneeuw KC, Brand R, Hille ET, den Ouden AL, Wit JM, et al. Catch-up growth up to ten years of age in children born very preterm or with very low birth weight. BMC Pediatr 2005;5:26. http://dx.doi.org/ 10.1186/1471-2431-5-26.

[17] Guo SS, Roche AF, Chumlea WC, Casey PH, Moore WM. Growth in weight, recumbent length, and head circumference for preterm lowbirthweight infants during the first three years of life using gestationadjusted ages. Early Hum Dev 1997;47(3):305-25. http://dx.doi.org/ 10.1016/S0378-3782(96)01793-8.

[18] Bertino E, Coscia A, Boni L, Rossi C, Martano C, Giuliani F, et al. Weight growth velocity of very low birth weight infants: role of gender, gestational age and major morbidities. Early Hum Dev 2009;85(6):339-47. http://dx.doi.org/10.1016/j.earlhumdev. 2008.12.014.

[19] Hack M, Schluchter M, Cartar L, Rahman M, Cuttler L, Borawski E. Growth of very low birth weight infants to age 20 years. Pediatrics 2003;112 [1 Pt 1: e30-e38].

[20] Bangirana P, John CC, Idro R, Opoka RO, Byarugaba J, Jurek AM, et al. Socioeconomic predictors of cognition in Uganda children: implications for community interventions. PLoS ONE 2009;4 [e7898].

[21] Filmer D, Pritchett LH. Estimating wealth effects without expenditure data-or tears: an educational app to enrollments in states of India. Policy research working paper. The World Bank; 1994.

[22] Battaglia FC, Lubchenco LO. A practical classification of newborn infants by weight and gestational age. J Pediatr 1967;71:159-63.

[23] Mamelle N, Munoz F, Grandjean H. Fetal growth from the AUDIPOG study. Establishment of reference curves. J Gynecol Obstet Biol Reprod (Paris) 1996;25:61-70.

[24] WHO. Physical status: the use and interpretation of anthropometry. A postponement of a WHO Expert Committee. Geneva: WHO Technical Series Geneva; 1995.

[25] W.H.O. WHO multicenter growth reference study group WHO child growth standards: length/height-for-age, weight-for-age, weight-forlength. Geneva: WHO; 2006.

[26] W.H.O. WHO child growth standards based on length/height, weight and age. Acta Paediatr 2006;450:76-85.

[27] Ong KK, Ahmed ML, Emmett PM, Preece MA, Dunger DB. Association between postnatal catch-up growth and obesity in childhood: prospective cohort study. BMJ 2000;320:967-71.

[28] W.H.O. Indicators for assessing infant and young child feeding practices part 1: definition, conclusions of consensus meeting held 6-8 November 2007 in Washington DC. USA: WHO; 2008.

[29] W.H.O. Indicators for assessing infant and young child feeding practices part 1: country profiles. Geneva: WHO; 2010.

[30] Clark HR, Thomas P, Joyce J. Peabody extra-uterine growth restriction remains a serious problem in neonates born prematurely. Pediatrics 2003;111:986-90.

[31] Marks KA, Reichman B, Lusky A, Zmora E. Fetal growth and postnatal growth failure in very-low-birth weight infants. Acta Paediatr 2006;95(2):236-42.

[32] Faye PM, Diagne-Guèye NR, Paraiso IL, Bâ A, Guèye M, Dieng YJ. Croissance pondérale postnatale des nouveau-nés de faible poids de naissance au service de néonatologie du centre hospitalier national d'enfants Albert Royer : incidence du retard de croissance extra-utérin. J Pédiatr Puéric 2016;29:20-7.

[33] Barkat A, Kabiri M, Rezki A, Lamdouar Bouazzaoui N. Retard de croissance postnatale du prématuré : étude rétrospective à propos de 80 cas. J Pediatr Pueric 2009;22:23-8.

[34] Letaief M, Soltani MS, Ben Salem K, Bchir Mohamed A. Épidémiologie de l'insuffisance pondérale à la naissance dans le Sahel tunisien. Sante Publique 2001;13(4):359-66.

[35] Shan HM, Cai W, Cao Y, Fang BH, Feng Y. Ectopic growth retardation in premature infants in Shanghai: a multicenter retrospective review. Eur J Pediatr 2009;168(9):1055-9. 
[36] Sakurai M, Itabashi K, Sato Y, Hibino S, Mizuno K. Ectopic growth restriction in preterm infants of gestational age $<$ or $=32$ weeks. Pediatr Int 2008;50(1):70-5.

[37] Olusanya BO. Intrauterine growth restriction in a low-income country: risk factors, adverse perinatal outcomes and correlation with current WHO Multicenter Growth Reference. Early Hum Dev 2010;86(7):439-44.

[38] Olusanya BO, Wirz SL, Renner JK. Prevalence, pattern and risk factors for undernutrition in early infancy using the WHO Multicentre Growth Reference: a community-based study. Paediatr Perinat Epidemiol 2010;24(6):572-83.

[39] Bloss E, Wainaina F, Bailey RC. Prevalence and predictors of underweight, stunting, and wasting among children aged 5 and under in western Kenya. J Trop Pediatr 2004;50(5):260-70.

[40] Medhin G, Hanlon C. Prevalence and predictors of undernutrition among infants aged six and twelve months in Butajira, Ethiopia: the P-MaMiE Birth Cohort. BMC Public Health 2010;10:27.

[41] Maleta K, Virtanen SM, Espo M, Kulmala T, Ashorn P. Childhood malnutrition and its predictors in rural Malawi. Paediatr Perinat Epidemiol 2003;17(4):384-90.

[42] Dancis J, O'Connell JR, Holt LE. A grid for recording the weight of premature infants. J Pediatr 1948;33(11):570-2.

[43] Hay WW. Assessing the effect of disease on nutrition of the preterm infant. Clin Biochem 1996;29(5):399-417

[44] Embleton NE, Pang N, Cooke RJ. Postnatal malnutrition and growth retardation: an inevitable consequence of current recommendations in preterm infants? Pediatrics 2001;107(2):270-3.

[45] Canadian Pediatric, Society. Nutrient needs and feeding of premature infant's nutrition. Can Med Assoc J 2010;11:152.

[46] Lemons JA, Bauer CR, Oh W, Korones SB, Papile LA, Stoll BJ, et al. Very low birth weight outcomes of the National Institute of Child health and human development neonatal research network, January 1995 through December 1996. NICHD Neonatal Research Network. Pediatrics 2001;107(1) [E1].

[47] Olsen IE, Richardson DK, Schmid CH, Ausman LM, Dwyer JT. Intersite differences in weight growth velocity of extremely premature infants. Pediatrics 2002;110(6):1125-32.
[48] Berry MA, Abrahamowicz M, Usher RH. Factors associated with growth of extremely premature infants during initial hospitalization. Pediatrics 1997;100(4):640-6.

[49] Kabore P, Potvliege C, Sanou H, Bawhere P, Dramaix M. Croissance pondérale et survie des enfants de petit poids de naissance nés à terme en milieu rural africain (Burkina Faso). Arch Pediatr 2004;11(7):807-14.

[50] Kalanda BF, van Buuren S, Verhoeff FH, Brabin BJ. Catch-up growth in Malawian babies, a longitudinal study of normal and low birthweight babies born in a malarious endemic area. Early Hum Dev 2005;81(10):841-50.

[51] Wamani H, Tylleskar T, Astrom AN, Tumwine JK, Stefan Peterson S. Mothers' education but not fathers' education, household assets or land ownership is the best predictor of child health inequalities in rural Uganda. Int J Equity Health 2004;3(1):9.

[52] Van de Poel E, Hosseinpoor AR, Jehu-Appiah C, Vega J, Speybroeck N. Malnutrition and the disproportional burden on the poor: the case of Ghana. Int J Equity Health 2007;6:21.

[53] Ukwuani FA, Suchindran CM. Implications of women's work for child nutritional status in sub-Saharan Africa: a case study of Nigeria. Soc Sci Med 2003;56(10):2109-21.

[54] Wamani H, Astrom AN, Peterson S, Tumwine JK, Tylleskär T. Boys are more stunted than girls in sub-Saharan Africa: a meta-analysis of 16 demographic and health surveys. BMC Pediatr 2007;7:17.

[55] Padonou G, Le Port A, Cottrell G, Guerra J, Choudat I, Rachas A, et al. Factors associated with growth patterns from birth to 18 months in a Beninese cohort of children. Acta Trop 2014;135:1-9.

[56] Wells JC. Natural selection and sex differences in morbidity and mortality in early life. J Theor Biol 2000;202(1):65-76.

[57] Warrington NM, Wu YY, Pennell CE, Marsh JA, Beilin LJ, Palmer LJ. Modelling BMI trajectories in children for genetic association studies. PLoS One 2013;8(1) [e53897].

[58] Bocca-Tjeertes I, Bos A, Kerstjens J, de Winter A, Reijneveld S. Symmetrical and asymmetrical growth restriction in preterm-born children. Pediatrics 2014;133(3):1-7. 